\begin{tabular}{|l|l|l|l|l|}
\hline Cuadernos de Investigación Geográfica & 2002 & N$^{\circ} 28$ & pp. 101-108 & ISSN 0211-6820 \\
\hline
\end{tabular}

(c) Universidad de La Rioja

\title{
FLOODS DOWNSTREAM THE YESA RESERVOIR, SPANISH PYRENEES
}

\author{
J. I. LÓPEZ-MORENO \\ S. BEGUERÍA \\ J. M. GARCÍA-RUIZ
}

Instituto Pirenaico de Ecología, CSIC, Campus de Aula Dei, Apartado 202, 50080-Zaragoza, Spain

ABSTRACT: This paper deals with the effects of the Yesa reservoir on the intensity and temporal distribution of floods in the Aragón River. The results confirm that the frequency of floods downstream the dam clearly decreased. The reduction mainly depended on two factors: $i)$ the water sto rage level, and ii) the season of the year. Floods were very well controlled when the reservoir level was lower than $50 \%$.

RESUMEN: Este trabajo estudia los efectos del embalse de Yesa sobre la intensidad y distribución temporal de las avenidas en el río Aragón. Los resultados confirman que la frecuencia de avenidas disminuye claramente aguas abajo de la presa. La reducción depende principalmente de dos factores: $i)$ el nivel de almacenamiento de agua, y ii) la estación del año. Las avenidas están muy bien controladas cuando el nivel del embalse es infe rior al $50 \%$.

Key-words: Reservoir, Flood control, Flood seasonality, Pyrenees.

Palabras clave: Embalse, Control de avenidas, Estacionalidad de avenidas, Pirineos.

\section{Introduction}

Reservoirs regulate discharge for many purposes including providing water for cities and industries, producing hydropower and to supply large irrigation areas with seasonally contrasted climates. Sometimes, reservoirs are managed to reduce the effect of floods downstream the dams, to avoid the coincidence of floods in rivers of the same basin. In other cases, floods contribute decisively to the infilling of reservoirs In this paper the effect of the Yesa reservoir on floods of the Aragón river is studied, as well as the variability of the flood control capacity throughout the year. The Yesa reservoir was constructed in 1959 for irrigation purposes. For this reason, water storage reaches a maximum at the end of spring, which brings about complex interactions between the process of infilling and the occurrence of floods.

\section{The study area}

The Yesa reservoir drains an area of $2,181 \mathrm{Km}^{2}$ in the Upper Aragón River Basin (Figure 1). Its altitude ranges between more than $2500 \mathrm{~m}$ in the north of the basin to less 


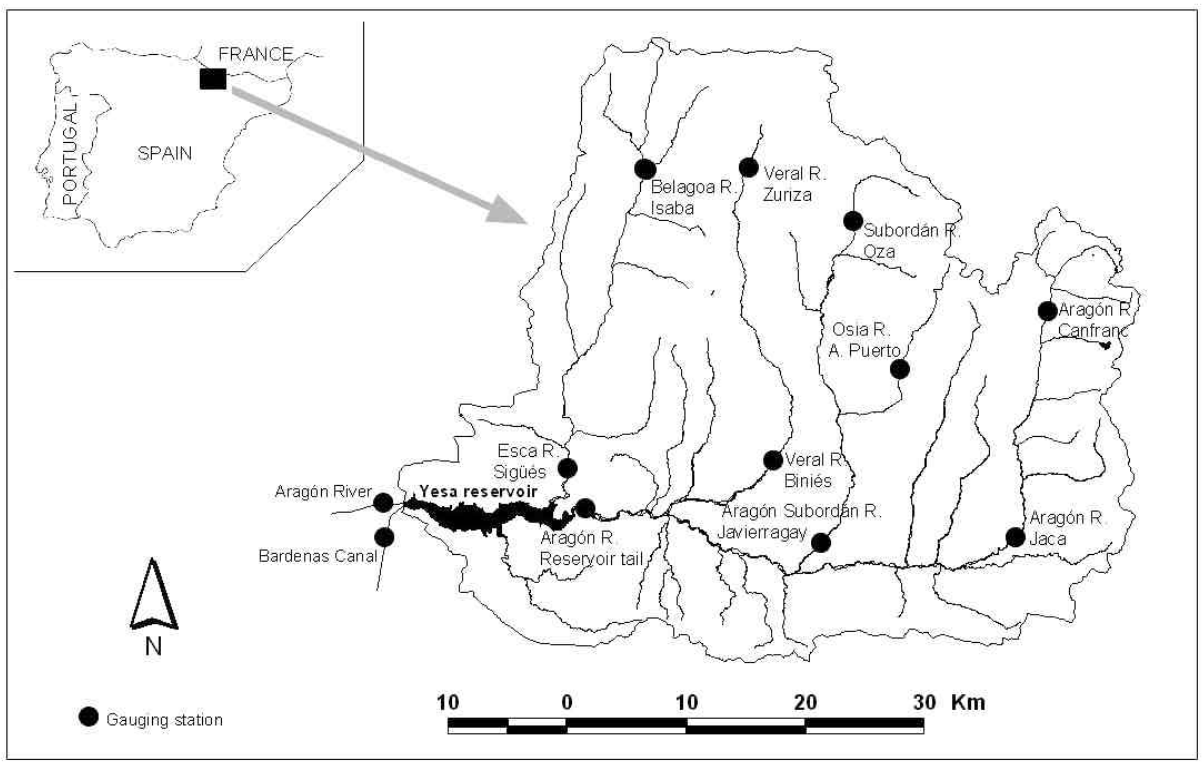

Figure 1. The study area.

than $500 \mathrm{~m}$ at the reservoir. The Aragón river runs north-south across a paleozoic area (limestones, shales and clays), the Inner Sierras (limestones and sandstones) and the Flysch Sector. Then it arrives to the Inner Depression (marls) and runs westward to the Yesa reservoir.

The Aragón River Basin occupies a transition area between the Atlantic (north and west) and Mediterranean (south and east) influences. The average annual precipitation in the northernmost sector of the basin is over $1500 \mathrm{~mm}$, and around $800 \mathrm{~mm}$ in the Inner Depression. The wet season is from October to June, with more precipitation in autumn and, secondarily, in spring. Intense rainfall can occur at any time of the year (García-Ruiz et al., 2001; White et al., 1997), though its frequency and intensity is higher in autumn.

The Yesa dam was built in 1959. Its original capacity was $470 \mathrm{Hm}^{3}$. The main aim of the reservoir is to supply irrigation water for 60,701 ha via the Bardenas Canal, which begins at the foot of the Yesa dam.

The inflow to the reservoir is basically the sum of the Aragón and Esca Rivers. The outflow is the sum of the water diverted to the Bardenas Canal and the discharge released to the Aragón River downstream the dam.

Figure 2 shows the regimes of the Aragón River (at the tail of the reservoir), the Esca River (at Sigüés) and the total inflow to the reservoir. The Esca river has a clear oceanic regime, with high flows between December and April (maximum in February). The mean contribution of this river to the Yesa reservoir is $353 \mathrm{hm}^{3}\left(12.1 \mathrm{~m}^{3} \mathrm{~s}-1\right)$. The Aragón River contributes $1,019 \mathrm{hm}^{3}$ per year $\left(32,6 \mathrm{~m}^{3} \mathrm{~s}^{-1}\right)$ to the reservoir. It has high discharges 


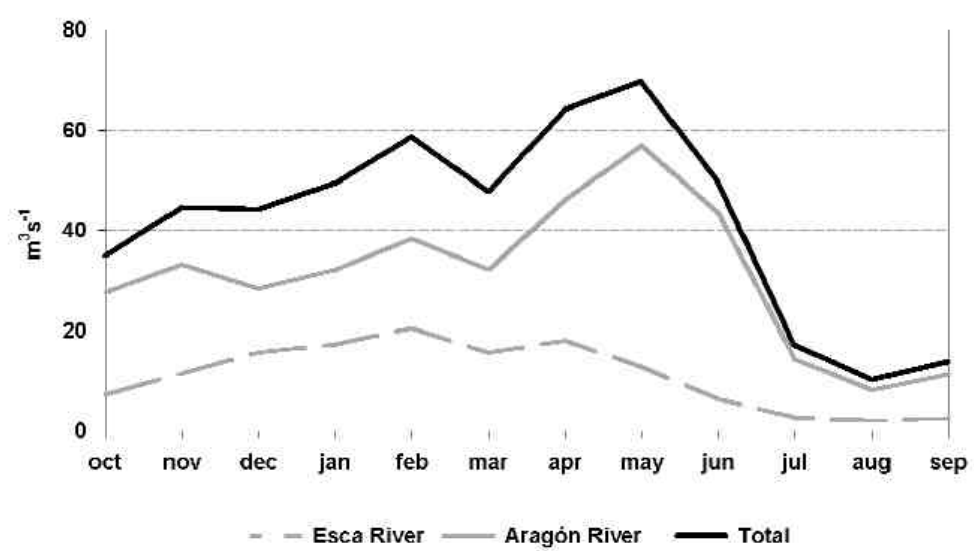

Figure 2. The inflow contribution to the Yesa Reservoir (Aragón and Esca rivers, and the total inflow).

in spring, when snowmelt coincides with a secondary maximum of precipitation, decreasing sharply after June. There is a long period of relatively high discharge in autumn and winter, especially in November and February. Floods are more frequent in spring, especially in May and April, though the most extreme floods tend to occur in November. The total contribution of both rivers to the reservoir is $1372 \mathrm{hm}^{3}\left(44 \mathrm{~m}^{3} \mathrm{~s}^{-1}\right)$.

The water storage level (Fig. 3) begins to rise in October. The maximum stored volume is reached in May and June in order to attend the high water demands in summer when inflows are very low. Storage levels increase greatly in autumn and spring. In winter, most of the inflow is released as a safety measure against spring floods. During summer the stored volume quickly decreases from July to September (López-Moreno et al., 2000).

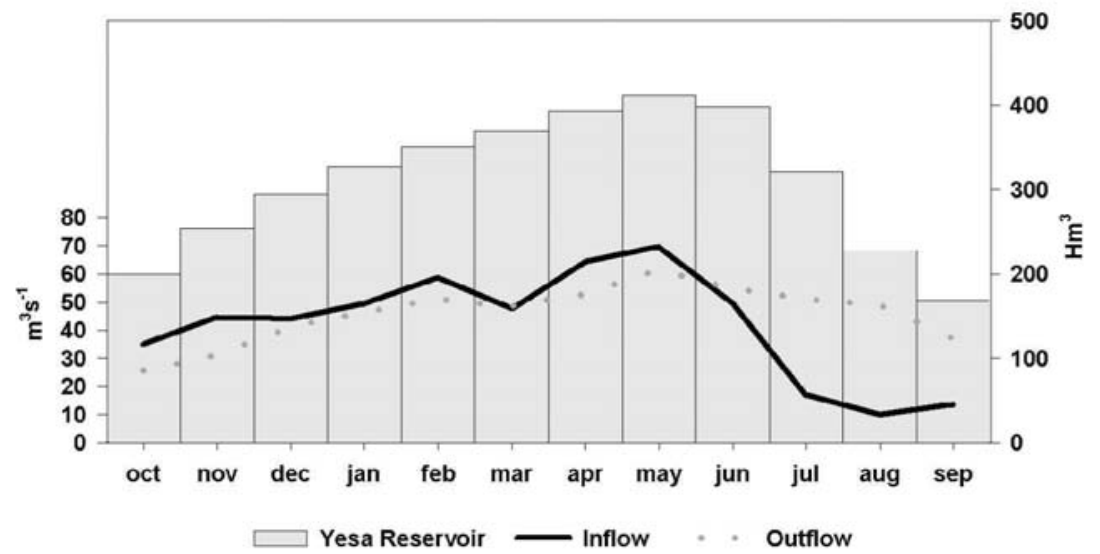

Figure 3. Average monthly volume stored in the Yesa reservoir and the balance between inflow and outflow discharge. 


\section{Methods}

Information about the reservoir regime was provided by the Ebro River Hydrographic Administration (Confederación Hidrográfica del Ebro). Gauge stations provided daily information about the Aragón River discharge at the tail of the reservoir and the Esca River. The sum of both rivers made up most of the inflow to the reservoir. The outflow was calculated as the sum of the Aragón River in Yesa (downstream the dam) and the water diverted to the Bardenas Canal.

The effects of the Yesa reservoir on floods has been studied by comparing the daily data between the inflow and outflow series from 1959-2000 (since the construction of the reservoir). This procedure enables us the information upstream and downstream of the reservoir using the same time series. In this paper, both series were used to calculate the return period curves by applying the General Pareto Model to Partial Duration Series over the centil 97. The return period curves were calculated for different levels of water storage to analyse its influence throughout the infilling period. The intensity-frequency curves were also obtained for upstream and downstream data series.

The average amount of floods per month was calculated for both inflow and outflow discharges in order to compare the seasonal effect.

\section{Results and discussion}

When the reservoir was below $50 \%$ capacity (around $225 \mathrm{Hm}^{3}$ or less), the flood control capacity was almost total. Thus, there was a rapid separation of inflow and outflow curves, confirming that the outflow discharges maintained the same level, even for floods corresponding to more than a 100-year return period (Figure 4a). At 70-90\% capacity, flood control decreased sharply (Figure 4b). There was almost no reduction of peakflows for floods corresponding to less than 10 year return period and a limited flood control was found for large floods (100 year return period).

Above $90 \%$ capacity (Figure 4c), floods could no longer be laminated and the discharge corresponding to any return period was similar for both the inflow and outflow discharges. During large floods, the peakflow downstream the dam was even higher than the inflow. These large floods are related to intense storms that affect the whole Upper Aragón River Basin, when reservoir managers are afraid for the safety of people and fields downstream (García-Ruiz et al., 1983). Higgs and Petts (1988) also point out that peakflows can be higher downstream a dam than upstream, especially in the case of hydropower plants.

Water storage at the Yesa reservoir increased from October to May-June, with two main periods of infilling in autumn and spring (Figure 3). In fact, the reservoir managers tried to retain a large proportion of the autumn discharge in order to quickly increase the water storage. After this, spring high flows ended the process of infilling. Figure 5 shows the percentage of water storage in autumn and spring, in relation to the total storage capacity of the Yesa reservoir. It was quite variable in autumn, since almost any storage 


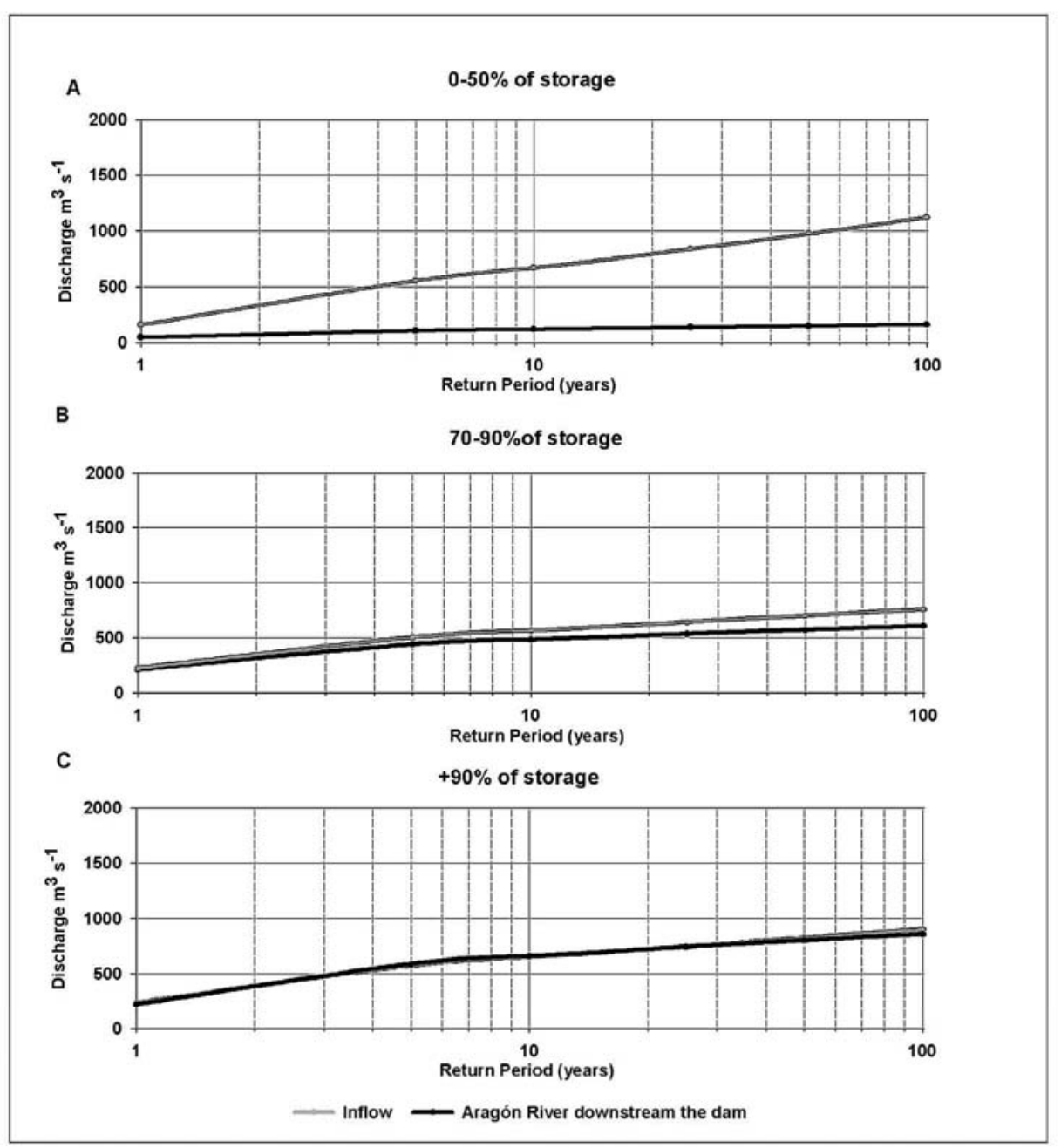

Figure 4. Return period curves for different water storage levels in the Yesa reservoir.

level is possible due to the variability of autumn rainfalls in the Mediterranean environments. After the summer many days were normally needed to re-start a rapid infilling of the reservoir. In spring, the reservoir was usually at $70-80 \%$ of its capacity, especially at the end of the season.

Figure 6 illustrates the number of floods, month by month, and compares the inflows (Aragón and Esca rivers) and the outflows (Aragón river at the foot of the dam. The inflow floods occur between October and June, with very few in summer. Most floods occur in May, followed by April, February and November. Floods are infrequent in December and March, as well as in the summer months. 

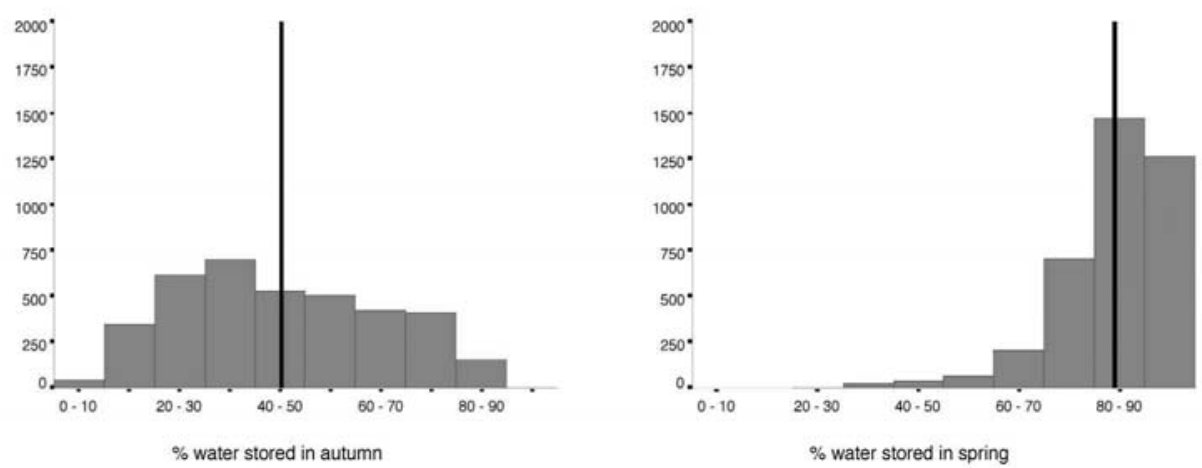

Figure 5. Histograms of frequency of water storage level in autumn and spring.
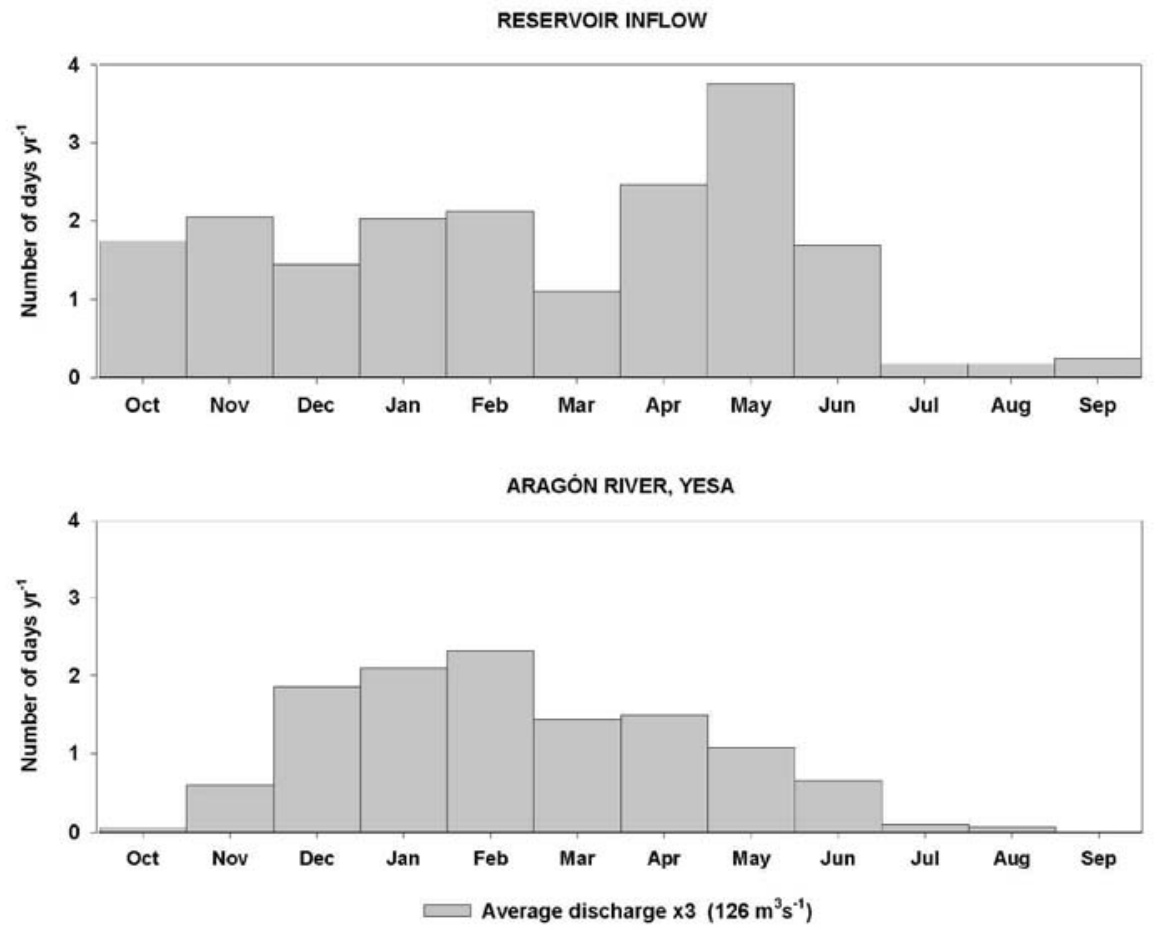

Figure 6. Frequency of upstream and downstream floods along the year.

The distribution of floods was very different downstream the dam. They clearly decreased in October and November and in April, May and June (Figure 6). There were no floods in October since the reservoir was at its lowest level, and almost the same occurred in November. The spring floods were used to finish the process of infilling before summer releases. 
Given the regular occurrence of springtime floods year after year (due to the regularity of snowmelt and spring rainfalls), the reservoir managers relied on them to completely infill the reservoir. For this reason they released all the inflows between December and March. Floods can even increase in December, February and March as water is released in relation to the expected spring discharges.

The seasonality of reservoir effects has also been reported in some British rivers. In the River Hodder, Higgs \& Petts (1988) find that the effect of the reservoir is greater during the summer. The magnitude of a 5-year winter flood only decreased $8 \%$ after the construction of the reservoir, whereas a 5-year summer flood decreased 50\%. In Austrian rivers, reservoirs also have clear seasonal consequences on floods. The biggest floods in summer are well controlled since the reservoirs do not complete filling until September or October (Pircher, 1990).

\section{Conclusions}

We considered the role of the Yesa reservoir in reducing floods in the Upper Aragón River, and its influence on the seasonality of floods. The main conclusions are:

i) The ability to control floods mostly depends on the volume of water stored in the reservoir. Floods were very well controlled when the reservoir capacity was less than $50 \%$. Between 50 and $70 \%$, only the highest floods (corresponding to more than a 10 year return period) were controlled, in order to avoid overflowing problems downstream. Above $90 \%$ capacity, there was almost no flood control and even higher floods could be recorded downstream due to sudden water releases for safety reasons. For large floods, the role of the reservoir was directly related to the water storage level, whereas there were many other management possibilities for the most frequent floods.

ii) The reservoir was mainly infilled with the autumn and spring high flows. For this reason, there was a clear reduction in the number of autumn and spring floods. Most winter floods were released downstream as a safety margin. Only the highest winter floods were controlled in order to avoid any coincidence with the floods in the Ebro River.

\section{Acknowledgements}

This work was partially supported by the research project «Water resources management in a changing environment: the impact of sediment in sustainability» (WARMICE, ENV4-CT98-0789), funded by the European Community, and two projects funded by the CICYT «Permanent stations to study hydrological processes in Mediterranean environments» (EPPROHIDRO, HID98-1056-C02-01) and «Assessment of sediment and runoff sources in relation to landuse changes» (HIDROESCALA, REN2000-1709-C04-01/GLO).

\section{References}

García-Ruiz, J.M., Puigdefábregas, J. and Martín-Ranz, M.C., (1983). Diferencias espaciales en la respuesta hidrológica a las precipitaciones torrenciales de noviembre de 1982 en el Pirineo Central. Estudios Geográficos, 170-171: 291-310. 
García-Ruiz, J.M., Beguería, S., López Moreno, J.I., Lorente, A. and Seeger, M., (2001). Los recursos hídricos superficiales del pirineo aragonés y su evolución reciente. Geoforma Ediciones, 192 pp., Logroño.

Higgs, G.P., and Petts, G., (1988). Hydrological changes and river regulation in the UK. Regulated Rivers: Research and Management, 2: 349-368.

López-Moreno, J.I., Beguería, S. and García-Ruiz, J.M., (2000). El régimen del embalse de Yesa (cuenca alta del río Aragón, Pirineo central) y su adaptación a la variabilidad del régimen fluvial. Cuadernos de Investigación Geográfica, 26: 131-145.

Pircher, W., (1990). The contribution of hydropower reservoirs to flood control in the Austrian Alps. In O. Sinniger \& M. Monbaron (eds.), Hydrology in Mountainous Regions. II Artificial Reservoirs: Water and Slopes. IAHS Publ., 194: 3-10.

White, S., García-Ruiz, J.M., Martí-Bono, C., Valero, B., Errea, M.P. and Gómez-Villar, A., (1997). The Biescas campsite disaster and its temporal and spatial context. Hydrological Processes, 11: 1797-1812. 